\title{
Green Economy or Living Well? Assessing divergent paradigms for equitable eco-social transition in South Korea and Bolivia
}

\author{
Karen Bell ${ }^{1}$ \\ University of Bristol, UK
}

\begin{abstract}
'Green Economy' and 'Living Well ('Vivir Bien)' have emerged as contending macro-policies in the search for a future direction that meets human needs whilst respecting environmental limits. There are a number of different interpretations of each concept but the dominant discourses in relation to each are distinct. Green Economy is presented as a fundamentally technological, managerial and market-based approach, whilst Living Well is considered to imply redistribution of wealth, inter-personal and inter-species reciprocity and eco-socialist development in harmony with nature. Contributing to the debate on the most effective strategic direction to take to achieve equitable and effective eco-social transition, this article examines the processes, politics and early impacts of attempts to implement these macro-policies in South Korea, a global Green Economy leader, and Bolivia, at the forefront of promoting the Living Well approach.
\end{abstract}

Key words: Environment, development, Vivir Bien, macro-policy, climate change, Global South

\section{Résumé}

La «économie verte» et «Vivir Bien» (Living Well) ont émergé comme différentes macro-politiques dans la recherche d'une orientation qui répond aux besoins humains tout en respectant les limites environnementales. Il y a un certain nombre d'interprétations différentes de chaque concept, mais leurs discours dominants sont distincts. L'économie verte est présenté comme une approche fondamentalement technologique, fondée sur le marché et basé sur la gestion, tandis que Living Well est considérée comme impliquant une redistribution de la richesse, de la réciprocité entre les personnes et entre les espèces, et le développement de l'éco-socialiste en harmonie avec la nature. Contribuer au débat sur l'orientation stratégique la plus efficace à prendre pour parvenir à la transition équitable et efficace à l'éco-socialisme, cet article examine les processus, la politique et des premiers effets de tentatives pour mettre en œuvre ces politiques macroéconomiques en Corée du Sud, un leader mondial dans économie verte, et de la Bolivie, à l'avant-garde de la promotion de l'approche Living Well.

Mots clés: Environnement, développement, Vivir Bien, macro-politique, le changement climatique, le Sud Global

\section{Resumen}

'Economía Verde' y 'Vivir Bien' se han convertido en contendientes las macropolíticas en la búsqueda de una futura dirección que satisfaga las necesidades humanas, respetando los límites ambientales. Aunque hay muchas interpretaciones de cada uno, el discurso dominante sobre 'Economía Verde' presenta un enfoque fundamentalmente tecnológica, de gestión y basado en el mercado, mientras que la comprensión corriente principal de Vivir Bien es que se articula una perspectiva ecosocialista, abogando por la redistribución de la riqueza, la reciprocidad y el desarrollo en armonía con la naturaleza. Contribuir al debate sobre la dirección estratégica más eficaz de tomar para lograr la transición eco- social equitativo y eficaz, este trabajo analiza los procesos, la política y los impactos tempranos de los intentos de poner en práctica estas macro- políticas en Corea del Sur, líder mundial de Economía Verde, y Bolivia, a la vanguardia de la promoción del enfoque Vivir Bien.

Palabras clave: Medio ambiente, desarrollo, Vivir Bien, macro-política, el cambio climático, del Hemisferio Sur

\footnotetext{
${ }^{1}$ Dr. Karen Bell, ESRC Future Research Leaders Fellow, School for Policy Studies, University of Bristol, 8 Priory Road, Bristol, BS8 1TZ, United Kingdom. Email: karen.bell "at" bristol.ac.uk.
} 


\section{초록}

환경의 한계를 고려한 인간욕구 충족이라는 가치를 실현하기 위해 최근 “녹색경제” 와 "Living Well" ('Vivir Bien') 이라는 거시적 정책방향이 한국과 브라질 양국에서 각각 부각되었다. 녹색경제와 "Living Well" 을 어떻게 정의할지를 두고는 여러 해석이 존재하는 것이 사실이나, 이들 개념을 둘러싼 주요 담론들은 뚜렷한 경향을 드러낸다. 녹색경제는 근본적으로 기술적이고, 조직에 중점을 두며, 시장을 기반으로 한 접근인 반면, Living Well 은 부의 재분배, 인간 간 생물종들 간 상호호혜, 그리고 자연과 조화를 이루는 환경적 사회발전을 그 기치로 한다. 글로벌 그린 경제의 리더인 한국과 Living Well 접근의 선구자인 브라질에서 이러한 거시정책이 도입되는 과정, 역학관계, 그리고 도입 초기에 나타난 영향 등을 검증함으로써, 본 연구는 보다 평등하고 효과적인 환경적 사회로의 전환을 이루어내기 위한 전략적 접근에 대한 논의에 시사점을 제공한다.

\section{Introduction}

As the evidence mounts that the climate crisis has been caused by humans (e.g. IPCC 2013; Steffen et al. 2015), there has been a gradual but growing acceptance of the need for more environmentally harmonious societies. At the same time, traditional economic and political approaches are critiqued for their continuing failure to meet a number of basic human needs. For example, approximately one in three people globally are still without access to improved sanitation (UNICEF/WHO 2012); one in six lack access to electricity (IEA 2013); one in eight are without improved drinking water (UNICEF/WHO 2012); one in eight are without clean and safe cooking fuels (IEA 2013); and one in eight lack enough food to meet the minimum daily energy requirement (FAO, 2013). Furthermore, since 2008, many countries have been impacted by a deep economic recession which has widened and deepened poverty and deprivation.

Hence, many now agree that we need a fundamental change in our human activities, or an 'eco-social' transition, to address these crises and avert further catastrophic harm. Whilst there is no standard usage of the term 'eco-social' and it often lacks formal definition (e.g. Koch and Fritz 2014), it is generally used to describe integrated and progressive social and environmental policies, practices or institutions. For example, Gough refers to the need for a "unified eco-social policy that can achieve ecologically beneficial and socially just impacts" (2013: 199). It is this understanding of 'eco-social' that is discussed here in the context of considering how to transition to an ecological society whilst achieving greater equity in processes and outcomes.

Burke and Shear advocate researchers contribute to achieving such a transition through "...examining the tremendously diverse, already-existing experiments with other ways of being in the world" (2014: 130). In accord with this, there has been recent debate and comparative analysis of different models of 'environmental states' (see, for example, Duit 2015; Gough 2016; Koch and Fritz 2014 and Sommerer 2016). This article contributes to this debate, whilst focusing on the overall global trajectory of change, considering whether, for example, the global institutions should continue to support a fundamentally market-based approach to ecosocial transition or align themselves with a more radical alternative. These are crucial and timely questions since we have, perhaps, just twenty years within which to create the social practices that will enable us to avoid irreversibly overstepping planetary boundaries (Rockström et al., 2009; Steffen et al., 2015). We appear to be at a crossroads in terms of the diverging path that we could take. Hence, it is imperative that the steps we take now do not lead to a figurative or literal 'dead-end.'

Recent macro-'experiments' in new ways of bringing about eco-social transition at a national level include a 'green economy' (e.g. South Korea); an ecological civilisation (China); a sufficient economy (Thailand) and 'Living Well' (e.g. in Bolivia). Though there are overlaps and parallels among them, and they all claim to address environmental, social and economic crises simultaneously, they generally represent different and somewhat contradictory development directions. Therefore, it is vital to explore their consequences and implications. This article looks at two of these, the 'Green Economy' because it is currently the dominant model internationally, and 'Living Well', because it is the most radical alternative in terms of its ethos and values. 
The article is based on a comprehensive study of how to achieve environmental justice carried out by the author between 2008 and 2014. This research included six months of fieldwork; participatory observations; secondary quantitative and qualitative data analysis; and 140 interviews with a range of state representatives, civil society organizers, local 'experts', academics, workers and residents. Due to limited space, it is not possible to describe each method and its findings in sufficient detail here and so this article draws mainly on the interview and quantitative material, though it is important to point out that this data generally reinforced that derived from the other methods. With regard to the interviews, a minimum of twenty participants were included from each country, all leaders or spokespersons for much wider bodies e.g. national trade unions, Governmental environmental directorates, local and national NGOs. The interviewees were selected using 'purposive' (because they had particular knowledge or experience) and 'opportunistic' (because they were available) sampling methods. At the same time, care was taken to include a diversity of voices in each country, in terms of varieties of opinion, as well as demographic characteristics such as class, age and ethnicity. For example, the interview sample was made up of a 50/50 split of government opponents and supporters and a representative proportion of the class, age and gender structure of the country. The article focuses on one aspect of the overall study - the proposed strategic solutions to the multiple social, economic and environmental global crises. It begins with a brief outline of the theoretical underpinnings of the Green Economy and Living Well approaches and goes on to examine the lessons from their practical implementation in South Korea and Bolivia, so far. Overall, I will argue that the Living Well approach is more successful, even in this early stage, for achieving the kind of transition that is necessary to avert ecological and social catastrophe. However, it is also more challenging. Green Economy sits easily within a capitalist context, whilst Living Well does not. Hence, if adopted, Living Well will require a fundamental reassessment and reorientation of prevailing political, economic and social systems.

\section{The Green Economy and Living Well paradigms}

Whilst interpretations of Green Economy and Living Well vary and there is some overlap between them, their dominant interpretations are quite opposed. The two schools of thought are primarily divided with regard to their positions on:

- What the relative role of markets, state and community should be in achieving sustainability;

- whether it is necessary to maintain a growth based economy;

- whether environmental problems are technical or political;

- whether solutions can be applied incrementally within current structures, or whether they require profound and immediate structural change, and;

- the extent to which inequality must be addressed.

Their most striking point of departure is with regard to the issue of capitalism, with 'Green Economy' being typically promoted by capitalist states and their proponents, while 'Living Well' is only currently promoted by socialist or anti-capitalist leaning states and their supporters. The capitalist system is a point of contention among those who strive for environmental and social justice, with some believing that capitalism is compatible with, or even ideally suited to, the task of environmental transition (for example, Porritt 2007) whilst others suggest that the market economy, as the source of environmental and social crises, could never be part of a solution (for example, Magdoff and Foster 2011).

Living Well and Green Economy, therefore, generally attract support from different sides of the political spectrum. However, they are contested concepts and definitions vary so it is important to outline the range of interpretations of each. Hence, the next sections summarize the key definitions, contexts and arguments that pertain to each concept, beginning with Green Economy. It is important to note, firstly, that Green Economy is not an entirely new approach but, with the multiple crises of recent years, governments, policy-makers, businesses and policy-influencing groups have become particularly interested in the concept of late because of its inherent promise to kick start sluggish economies. A policy framework for the Green Economy has recently gained prominence through a series of reports and initiatives by the major supra- 
national development agencies, particularly the UNEP (2011); the World Bank (2012) and the OECD (2011; 2012a). While Shear (2014) sees Green Economy as encompassing a wide sphere of activity which may be capitalist, anti-capitalist or non-capitalist, the most dominant definitions describe it as a predominantly market-oriented (i.e. capitalist) approach, with the main role of governments being to provide enabling conditions and incentives for private investment or various 'nudges' to encourage different lifestyle choices (Cook 2012; Ferguson 2015; UNDESA 2012; UNEP 2011). The fact that environmental degradation has not been prevented in the past is attributed to market failures, such as not valuing natural capital sufficiently, and/or registering the costs of its degradation (OECD 2011; UNEP 2011). Hence, the Green Economy emphasizes economic growth, pricing mechanisms and technological innovation as the way to reduce social and environmental problems (e.g. UNEP 2011). It is considered that "...the greening of economies has the potential to be a new engine of growth, a net generator of decent jobs and a vital strategy to eliminate persistent poverty" (UNEP 2011: 16). Economic growth (defined here as an increase in the productivity of goods and services, as measured by GDP or GNP) is perceived as necessary to achieve sufficient jobs, prosperity and human wellbeing. Hence, the majority of national governments have consistently made it clear that they do not want to sacrifice growth for the environment. In the face of an increasing realization of the planetary limits to growth, they argue that it is not the amount of growth that matters, but the type of growth. It is proposed that 'Green-Growth' will simultaneously reduce greenhouse gas emissions and other environmental harms at the same time as stimulating economic recovery and, thereby, reducing global poverty and inequality. In 2009, all the countries of the Organisation of Economic Cooperation and Development (OECD) signed a Green Growth declaration committing them to pursuing Green Growth strategies (OECD 2012a). Following this in 2011, UNEP stated that:

The key aim for a transition to a green economy is to enable economic growth and investment while increasing environmental quality and social inclusiveness (UNEP 2011: 16).

One of the key arguments for 'Green Growth' is that, if sustainability and economic growth are presented as complementary, environmentalism is more likely to be taken seriously and acted upon (e.g. Borel-Saladin and Turok 2013; Hinterberger et al. 2009). Its proponents argue that alternative means of addressing the environmental, economic and social crises, such as moving away from marketization, consuming less, or banning harmful activities, are, naïve at best and, at worst, extremely detrimental to the goal of a better world. Reducing consumerism is considered to be a negative message for governments, businesses and citizens, implying job lay-offs, loss of profits, and self-denial.

However, when Green Economy was debated at the 2012 United Nations Conference on Sustainable Development (Rio+20), the concept and the underlying principles about how to achieve an equitable green transition were strongly contested by anti-capitalist and non-capitalist participants. Most of the critiques centered on the perceived neglect of the social consequences of the policy (e.g. People's Summit for Social and Environmental Justice 2012). Critiques of Green Economy came particularly from indigenous social movements, who warned that, though this approach promises to eradicate poverty, it actually favors corporate interests and will create more environmental problems though the promotion of risky technologies. For example, at the Indigenous People's Global Conference on Rio+20 and Mother Earth, the following appeal was made:

We urge all humanity to join with us in transforming the social structures, institutions and power relations that underpin our deprivation, oppression and exploitation....We need to fundamentally reorient production and consumption based on human needs rather than for the boundless accumulation of profit for a few...We demand that the United Nations, governments and corporations abandon false solutions to climate change, like large hydroelectric dams, genetically modified organisms including GMO trees, plantations, agro-fuels, "clean" coal, nuclear power, natural gas, hydraulic fracturing, nanotechnology, synthetic biology, bioenergy, biomass, biochar, geoengineering, carbon markets, Clean Development Mechanism 
and REDD+ that endanger the future and life as we know it (from the Kari-Oca II declaration, 'Indigenous People's Global Conference on Rio+20 and Mother Earth' 17 $7^{\text {th }}$ June 2012).

Criticism has also come from the national governments of a group of Latin American countries, specifically Argentina, Bolivia, Cuba, Ecuador, Nicaragua and Venezuela (UNEP 2013b; UNEP 2015). Most of these countries are aligned to ALBA, or 'The Bolivarian Alliance for the Peoples of Our America', an organisation based on the idea of social, political, and economic cooperation between the nations of Latin America and the Caribbean. ALBA is rooted in a socialist approach, and a vision of social welfare, mutual economic aid, the rights of indigenous people, social participation and fair and equitable distribution (Muhr 2013). In this spirit, these national Governments have expressed a great deal of concern with respect to the Green Economy paradigm. They do not consider it likely to reduce poverty or inequality and are concerned that any specific environmental improvements that do occur will be achieved at the expense of other ecological or social issues.

There have also been academic critiques of the Green Economy paradigm. For example, Victor and Jackson (2012) find problems with the UNEP (2011) report on the Green Economy on a number of grounds, but primarily because it underestimates the $\mathrm{CO}_{2}$ reduction necessary to avert the risk of catastrophic climate change; and because it assumes that investment in the Green Economy will be greater than in the Brown Economy. They conclude that:

...it is unlikely that reductions in $\mathrm{CO}_{2}$ emissions (not to mention other global environmental pressures) and significant closure of the gap between rich and poor (as required by a truly green economy) are simultaneously possible without some curtailment of ambitions for economic growth (Victor and Jackson 2012: 15).

Similarly, Brockington (2012), while enthusiastic about some of the radical implications of the UNEP report (2011), observes that it is ultimately conservative, being no more than a manifesto of mainstream sustainable development. He perceives that UNEP are positioning their discourse so as to gain maximum support from business and economic leaders and failing to sufficiently consider the social impacts of increased marketization. Moreover:

... the Report simply does not countenance the possibility of change which is not driven by ever-increasing consumption and expanding markets (Brockington 2012: 412).

Alongside these diverse criticisms and reservations with regard to the Green Economy paradigm, there have been a number of alternative proposals. One of the most radical of these is Vivir Bien (Living Well), sometimes also referred to as Buen Vivir, or Suma Qamaña in Aymara, Sumaj Kawsay in Quechua, or Ñande Reko in Guaraní. Rooted in the worldview of Andean indigenous groups, the concept of 'Vivir Bien' describes a communal approach to addressing the multiple environmental crises, whilst meeting human needs and achieving equality. It aspires to living in harmony with other human beings and nature in relationships of service and reciprocity; and subsumes all economic and social objectives to the protection of ecosystems, which are considered to be the foundation for the accomplishment of all social goals (Radcliffe 2012). Importantly, Vivir Bien implies that we are part of a whole, so that we cannot live well if other humans do not, or at the expense of our environment. It urges regulatory mechanisms and community participation in decision making to address environmental issues and eradicate poverty, and it inherently critiques the accepted need for economic growth, emphasizing meeting needs and satisfying rights. Under this ethos, the economy is based, not on the profit motive, but respect and care for humans and the rest of nature in a spirit of solidarity. Hence, Living Well differs from traditional understandings of wellbeing and development in its critique of anthropocentrism; individualization of satisfaction; paternalism; capitalism; perpetual economic growth; material accumulation and the commodification and mercantilization of nature (see, for example, 
Gudynas 2010). Living Well has, so far, been introduced into the Constitutions and development plants of two Latin-American countries: Bolivia and Ecuador. However, interest in the approach is spreading rapidly in the Global South. The Summit of the Group of 77 plus China, now chaired by Bolivia, marked the alliance's $50^{\text {th }}$ anniversary in 2014 with the adoption of a declaration 'For a New World Order for Living Well' laying out commitments to eradicating poverty, eliminating racism, gender equality, reducing inequality, raising basic living standards and development in harmony with nature (UN 2014).

Unlike the criticisms of the Green Economy, there has been no direct critique of Living Well as a policy orientation (although there have been critiques regarding how it has been implemented, as will be discussed later). The virtual silence may be because it is not yet being taken sufficiently seriously as a development alternative by the supra-national agencies, despite some recent acknowledgements of its existence and value (e.g. UNEP 2013b; UNEP 2015).

In general, the Green Economy and Living Well paradigms have been developing in parallel, with little evidence-informed debate. On the rare occasions that they have been compared, there has been a tendency to promote one or the other approach without referring to the impacts from their practical application (e.g. Pachero 2013). This article addresses this gap by examining how the two macro-policies have so far manifested in practice, focussing on South Korea (Green Economy) and Bolivia (Living Well), each global leaders in their respective approaches.

South Korea and Bolivia are useful cases to compare because they exemplify quite extreme versions of each model or paradigm, and this is useful for identifying potential impacts (as the impacts may, consequently, also be more extreme). Furthermore, they were both the earliest adopters of these paradigms and each country is widely viewed as the key leader in their respective approach (e.g. UNEP 2013; 2014). However, they begin from very different starting points. South Korea is a high income and developed country with a very short colonial past (colonized by Japan from 1920 to 1945) whilst Bolivia is a middle income country with an extensive colonial history. It is important to take these different contexts into account in the analysis. With this in mind, the next sections provide some relevant background to the countries before outlining the relevant processes and impacts of the respective policies in South Korea and Bolivia.

\section{Green Economy and Living Well in practice}

\section{Green Economy in South Korea}

South Korea has been applauded internationally for its apparent economic and social progress, particularly in terms of growth. Over the last six decades, the country has transformed itself with very fast export-fuelled economic growth and rapid industrialization, and its GDP is now the $15^{\text {th }}$ highest in the world. However, its greenhouse gas (GHG) emissions have rocketed over this period (see Table 5). South Korea is also one of world's largest energy consumers and currently imports approximately 96 percent of the energy that it uses in the form of oil, coal and liquefied natural gas (IEA 2012). Its energy use has been increasing in recent years. Between 2000 and 2010, the country's total final consumption of energy (TFC) increased by 24 percent (IEA 2012). Therefore, in order to continue to grow but become more energy independent and reduce its climate emissions, the government has embraced and developed 'Green-Growth' policies. This process was initiated by former president, Lee Myung-bak who, in 2008, proposed that 'Low-Carbon Green Growth' (LCGG) should be the new national development paradigm for the next 60 years (NRCS 2012). As a result, a Presidential Committee on Green Growth and a Low-Carbon Green Growth strategy was launched. The strategy was essentially a fiscal stimulus program, targeting 2.6 percent of GDP to ostensibly green initiatives.

Most academics and NGOs (Korean and external), as well as key supra-national organizations, frame South Korea's environmental project as Green Economy (e.g. UNEP 2014; WRI 2011; Yun and Cho 2011). For example, UNEP showcases Korea's Green Growth projects and programs under its Green Economy Initiative (UNEP 2014). The Korean government, whilst more frequently using the discourse of Green Growth, uses the terms Green Growth and Green Economy interchangeably, or subsumes Green Growth 
under Green Economy. Hence, the Korean Statistics Agency (KORSTAT) uses Green Growth Indicators (GGIs) as key measures of the country's Green Economy performance (Min 2015).

The Government laid out three objectives for Green Growth/Green Economy: economic growth with minimal use of energy and resources; reduced $\mathrm{CO}_{2}$ emissions and environmental pollution with the same energy and resource use; and new growth through research and development in green technologies, so as to achieve early dominance in international markets. The Low Carbon Green Growth strategy was to be implemented mainly through incentives for companies to develop green technologies and products; public information/education to increase awareness and demand for green products; and regulatory measures (particularly the reduction of greenhouse gas emissions from industry).

Though not required to reduce emissions under the Kyoto Protocol due to their developing economy status at the time of the negotiations, in 2009 the Government set a greenhouse gas reduction target of 30 percent by 2020, the most ambitious target of the Non-Annex I countries to date. In order to achieve this, a Target Management System (TMS) was initiated, setting emissions targets for 470 participating companies. The Government provided a great deal of financial assistance to enable the targeted companies to comply, subsidizing up to 50 percent of the cost of installing energy-efficient and low-carbon facilities, as well as offering loans and tax exemptions for the remaining costs. The TMS became the precursor for an Emissions Trading Scheme (ETS), adopted in 2012 by the South Korean National Assembly, making it one of the first governments in the world to set up such a scheme (IEA 2012). The South Korean carbon market is now the world's second largest, after the European Union Emissions Trading Scheme (EU ETS).

In addition to this, innovation and new technology is an important pillar of the Green Economy approach in South Korea, supported by billions of dollars of public finance (Ministry of Knowledge Economy, 2009). Financial incentives are available for different phases of environmental business development, including research and development, and commercialization. Alongside some clearly beneficial technologies, such as photovoltaic panels, wind energy technology and Light Emitting Diode (LED) appliances; the Government also plans to support development of the following more controversial technologies: fuel cells; carbon capture and storage (CCS); nuclear reactors; green cars; bio-technology; robot applications; nano-fusion; and bio-pharmaceuticals (Ministry of Knowledge Economy 2009; National Science and Technology Council 2009; Presidential Council for Future and Vision 2009). The Government has designed various financial policies to mobilize public funds for credit to environmental businesses through public financial institutions, such as the Korea Development Bank and the Korea Credit Guarantee Fund.

Much Korean environmental education is focused on stimulating demand for green products and encouraging individual green behavior patterns (see GGGI 2011). To help develop the market for ecological products, the Government introduced a mandatory eco-friendly product procurement scheme for public institutions and provides incentives, as well as practical information, to encourage citizens to shop green. For example, commercial banks have been encouraged to give preferential rates to customers who purchase ecoproducts with a specific credit card linked to their account (Kang et al. 2012). In addition, for the last 20 years, the Government has managed an eco-labelling system which provides consumers with environmental product information.

Hence, with its focus on trading, private sector innovation, individual consumption practices and subsidies to private companies, the South Korean Government has been at the forefront internationally of promoting and developing a market led interpretation of the Green Economy. In 2010, the Government helped to set up the Global Green Growth Institute (GGGI), which it now leads, dedicated to diffusing green growth around the world (GGGI 2013). The underlying assumption, as outlined in their 'vision' is:

...the belief that economic growth and environmental sustainability are not merely compatible objectives; their integration is essential for the future of humankind (GGGI 2013:1). 
South Korea's Green Economy program has been lauded by the OECD, UNEP, World Bank, IEA, the G8 and the G20, For example UNEP presented South Korea as a model green transition nation, stating, for example:

Beyond its policies at the national level, the Republic of Korea is demonstrating engagement and leadership at the international level by boosting global efforts towards achieving a green economy ... UNEP and the Republic of Korea are collaborating to support initiatives on green economy in developing countries (UNEP 2014: 1).

The South Korean Green Growth/Green Economy advocates interviewed for this study had high hopes for this policy. For example, one of the interviewees said:

The Green Economy is our best hope for preventing more environmental degradation, and our Low Carbon Green Growth Strategy is the practical application of that. We seek to transform economic growth so as to achieve sustainable development. There is going to be a big leap forward in environmental achievements in Korea. What's more, this is a policy that is led by developing countries (interview $12^{\text {th }}$ October 2012, Policy Executive, Government of the Republic of Korea).

However, most of those interviewed had doubts and reservations, if not outright hostility, towards Green Economy as implemented in South Korea. This seems to reflect the dominant national opinion. A representative from the Korean Citizens Movement for Environmental Justice estimated that most environmental organizations and up to 70 to 80 percent of the Korean people are against major portions of the Green-Growth platform (e.g. interview, 21 January 2013, Heeseon Sim, Policy Officer, Citizens Movement for Environmental Justice). Strong internal opposition to the Green Economy/Green Growth programs has come from Korea's trade unions and social movements, including the Citizens' Movement for Environmental Justice; Green Korea United; the Korean Green Party (Plus); Federation of Korean Trade Unions; Korean Federation of Construction Industry Trade Unions; Korean Power Plant Industry Union; and the Korea Peasants League. These groups refer to the Green Economy and LCGG strategies as 'green wash', warning that the portrayal of this program as a successful model by the international community is based on a lack of understanding and knowledge of what is really happening in South Korea. They have stated:

The world has been deceived by the Korean government's new vision for 'Green Growth'... this Green Growth policy currently touted in Korea is no more than an economic development vision ... Large scale civil engineering projects and constructions, such as nuclear power plants, are driving the Korean environment into a catastrophe (COP15 Korea NGOs Network 2009).

Their criticisms include, the lack of focus on reducing energy use; the planned increase in nuclear power; the low renewable energy targets; the focus on developing an overseas food supply; the emphasis on road transport, as opposed to railways; the increased privatization of resources, including water; the emphasis on projects which benefit developers at the expense of the environment; and the proposed deregulation of some environmental legislation (e.g. interview, 21 January 2013, Heeseon Sim, Policy Officer, Citizens Movement for Environmental Justice).

These concerns appear to be valid, according to the quantitative data and policy documentation I reviewed. Energy use, including coal and oil, continues to increase at an alarming rate (Korean Environment Statistics Information Service 2014; data to 2012). At the same time, as Joung-Woo et al. (2012) point out, 1.2 million South Korean households experience 'fuel poverty', spending more than 10 percent of their income on energy. Furthermore, though renewables are to be developed in a bid to enable the country to gain an advantage in the world market for low-carbon technologies (Kang et al. 2012), up to 50 percent of the energy 
required to grow the economy will be provided by nuclear power (Sanders 2010). Hence, 12 additional nuclear power plants will need to be built, in addition to the existing 20 (Sanders 2010). Moreover, agricultural outsourcing has continued apace, as was attempted in the now-infamous Daewoo LogisticsMadagascar deal of 2008. Half of Madagascar's arable land, as well as some rainforests, were to be converted into palm and corn monocultures for South Korea's food and energy consumption, while much of the local population went hungry. This 'land grab' attracted particular attention because of its size (1.3 million hectares) and the ensuing riots and overthrow of the Madagascan government. The Government's LCGG strategy has also included the deregulation of factory sites and the lifting of greenbelt restrictions within the Seoul region to enable more growth and development, including previously prohibited building on mountainsides. Furthermore, large scale engineering projects have been an important part of the strategy. For example, the controversial 'Four Rivers Restoration Project' was proposed to dredge, dam and 'beautify' four major rivers, supposedly to increase the supply and quality of fresh water and prevent flooding and drought as an adaptation to climate change. The project accounted for 36.8 percent of the budget for the government's Green Economy program, the highest share (Yun 2010). Although more than 70 percent of Korean citizens criticized the project on the grounds that it would kill the ecosystems of the four rivers, the project proceeded without respect for legal process (Yun 2010). A number of the interviewees expressed concern about this, asserting that the Government undertook these projects primarily for the benefit of the large civil engineering and building companies that were awarded contracts (e.g. interview, 1 February 2013, Yujin Lee, Director of Policy Making Committee, Korean Green Party Plus). The LCGG strategy will not even succeed in lowering carbon emissions, they argued, as South Korea's carbon footprint could increase with the resulting burst of construction. Hence, one high level state executive stated:

Many of us are concerned about the Green-Growth strategy. I think, mostly, this strategy is to incentivize industry which produces environmental goods, for example, companies producing wind and solar power generators ... It is not exactly an environmental policy, it is more a business strategy and, more controversially, it emphasizes nuclear energy as an alternative energy to oil. But the nuclear waste problem has not been solved in Korea so it will be a great problem if this strategy continues to be implemented (interview $9^{\text {th }}$ October 2012, Social Policy Executive, Government of the Republic of Korea).

Korean academics have also been critical of the LCGG strategy. For example, Yun (2010) argues that the Government's proposed policies and projects are based on a distorted and narrowed concept of 'green', purely focusing on carbon emissions. Yun considers that this policy is being used to make the active pursuit of growth more palatable and to narrow the acceptability of environmental policies that are not combined with growth. This co-option of the green agenda has, to some extent, taken the attention away from the domestic environmental movement and subsumed 'green' under what amounts to a growth-biased discourse.

Even pro-Green Economy analysts in South Korea have significant reservations. Rhee et al. (2012), for example, report that though greenhouse gases have reduced since the LCGG strategy was announced, the rate at which this has occurred indicates that the overall reduction will only be approximately 42 percent of that planned (Rhee et al., 2012). Furthermore, they point out:

... the biggest stakeholder of all, the general public of Korean society, is not well informed about the national green growth strategies. This is partly because the detailed contents are not fully open yet and also because the policy-making processes are practically closed to the general public (Rhee et al. 2012: 35-36).

Hence, though it is too early to judge the longer term outcomes of this policy, it has a number of worrying aspects, in terms of promoting many risky and/or ineffective technologies and programs. It could be argued that continuous growth is necessary to deliver improved human wellbeing, and so Green Growth 
should be the preferred option for eco-social transition. However, growth has not improved social outcomes in recent years. In spite of sustained growth in the five years to 2011, the share of the Korean population living on less than 50\% of the median income increased from 14.3\% to 15.2\% (OECD 2012c). In addition, though welfare provision in South Korea has been expanding over the last fifteen years (Ringen et al. 2011), social insurance programs, including pensions and social security after employment loss, still cover less than half of the population in the relevant categories (Kwon 2014). Social spending stands at only 8.1 percent of GDP. This is low by international standards, with the average OECD spending being 19.8 percent of GDP (JoungWoo et. al. 2012; 2011 data). Furthermore, the relative poverty rate in South Korea doubled between 1996 and 2008 during a period of very high growth (Jones and Yoo 2012). High inequality continues and is visibly evident (see Figure 1). Therefore, the OECD has made a statement regarding the need for Korea to look beyond growth in its policies, stating:

While economic growth can help reduce income inequality and poverty, Korea's experience shows that achieving a high growth rate is not sufficient in itself to address inequality and poverty (OECD 2012b: 1).

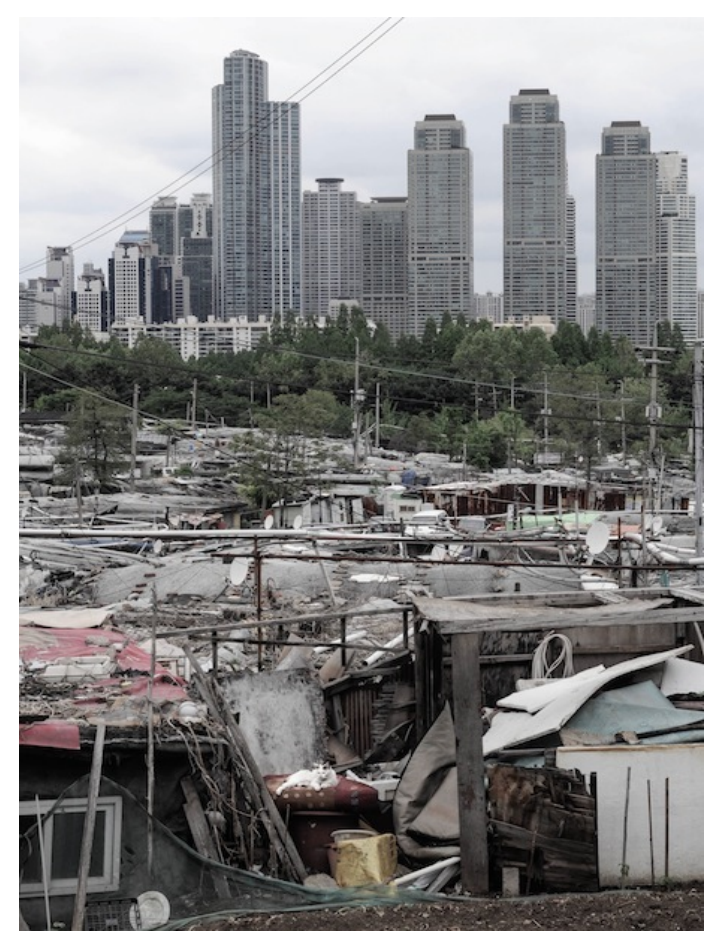

Figure 1: Gangnam Style? Inequality in Seoul showing prosperous Gangnam in the distance and poverty stricken Guryong in the foreground. Source: Mike Stulberg (2013).

Neither has growth in South Korea been successful in improving human rights. According to a recent report of the International Trade Union Confederation, South Korea sits in category 5 for employment rights, making it one of "the worst countries in the world to work in" (ITUC 2014a:15). An international delegation of trade union groups, including ITUC, reported on the human rights situation in the country in terms of the Korean government "...engaging in a wave of intense repression against labour and civil society of the kind not seen in recent years and which threatens to hollow-out the country's democracy" (ITUC 2014b: 1). 
Furthermore, there is no evidence that growth in the country has enhanced psychological wellbeing. Suicide rates have almost doubled over the last ten years so that the country now has the second highest suicide rate in the world (Värnik 2012). Park (2013) considers these rates have increased because younger South Koreans, in particular, are caught in cultural clashes between the new individualistic and intensely competitive economy impacting on school and the workplace, and the older Confucian expectations of reciprocity and caring for the family. These competitive pressures seem to be just as implicit in the Green Economy as the Brown Economy.

Perhaps because of the internal criticisms of Green Economy implementation in South Korea, there has been some faltering of the project over the last year or so. The Presidential Commission on Green Growth, set up by Lee in 2008, was down-graded to a ministerial committee by the new Park Government and a number of the 'green' ministries were down-sized and re-named. The Government ministers seemed to be keen to distance themselves from their predecessors' legacies, though they have now re-embraced the project under a new guise, embarking upon 'Green Growth 2.' This does not seem to indicate a change of direction, but rather a change of packaging so as to break the public association with some of the less popular aspects of the program, such as the 'Four Rivers Restoration Project.'

Although the outcomes of the Green Economy project in South Korea are still uncertain, the evidence from this initial overview indicates that this approach, as enacted in South Korea, does not protect the environment or deliver social necessities in a holistic way. Some of the solutions being proposed and implemented, such as developing risky technology and outsourcing agriculture, merely displace problems geographically, historically or socially. Though some environmental improvements may occur as a result of better management practices, incentives to change consumer habits, investment and new regulations, in general, Green Economy does not seem to support an effective and equitable eco-social transition. The kinds of policies and programs that have been implemented as part of the Green Economy in South Korea have even been socially and environmentally deleterious on occasion, suggesting that the Green Economy policy could be very problematic if adopted on a global scale. The next section examines one of the proposed alternative approaches - Living Well, as implemented in Bolivia.

\section{Living Well in Bolivia}

Whilst a number of governments are interested in the Living Well concept (World Bank 2015a), the Bolivian Government was the first in the world to fully embrace this philosophy. According to the 2009 constitution, all development projects should now be evaluated through a lens of Vivir Bien. The approach was further strengthened with the passing of the 'Framework Law of Mother Earth and Integral Development for Living Well' in 2012. This national legislation established 11 new rights for nature, including: the right to life and to exist; the right to continue vital cycles and processes free from human alteration; the right to pure water and clean air; the right to balance; the right not to be polluted; the right to not have cellular structures modified or genetically altered; and the right not be affected by mega-infrastructure and development projects that affect the balance of ecosystems. A new office has now been set up to roll out the program - the 'Plurinational Authority for Mother Earth' within the Ministry of Environment and Water. The first activity of this office was to organize the First National Workshop on Climate Change Policies which included social, academic, public and private organizations and representatives looking at how to increase community participation in the development of climate change policies.

Many formal policies, legislative proposals and training programs are still in the process of being set up but we can already see some indication of environmental and social achievements resulting from the Living Well paradigm. Since the MAS government came to power and, particularly with the initiation of the Living Well policy, Bolivia has stabilized or reduced a number of environmental harms, including many which have worsened under Green Economy in South Korea. This includes energy use and C02 and Greenhouse Gas emissions (see Tables 1, 2 and 3). 


\begin{tabular}{|l|l|l|l|l|l|l|l|l|l|l|l|}
\hline & 2004 & 2005 & 2006 & 2007 & 2008 & 2009 & 2010 & 2011 & 2012 & 2013 & 2014 \\
\hline Bolivia & 662 & 697 & 834 & 704 & 737 & 759 & 756 & 779 & 831 & & \\
\hline Korea & 4,337 & 4,368 & 4,419 & 4,573 & 4,639 & 4,661 & 5,060 & 5,232 & 5,268 & 5,222 & \\
\hline
\end{tabular}

Table 1: Energy use (kg of oil equivalent per capita). Source: World Bank 2015 Energy use (kg of oil equivalent per capita)

http://data.worldbank.org/indicator/EG.USE.PCAP.KG.OE/countries?page=1

\begin{tabular}{|l|l|l|l|l|l|l|l|l|l|l|l|}
\hline & 2004 & 2005 & 2006 & 2007 & 2008 & 2009 & 2010 & 2011 & 2012 & 2013 & 2014 \\
\hline Bolivia & 1.5 & 1.3 & 1.6 & 1.3 & 1.4 & 1.5 & 1.5 & 1.6 & & & \\
\hline Korea & 10.0 & 9.6 & 9.7 & 10.2 & 10.4 & 10.3 & 11.5 & 11.8 & & & \\
\hline
\end{tabular}

Table 2: $\mathrm{CO}_{2}$ emissions (metric tons per capita). Source World Bank $2015 \mathrm{CO}_{2}$ emissions per capita. http://data.worldbank.org/indicator/EN.ATM.CO2E.PC?page=1

\begin{tabular}{|l|l|l|l|l|l|l|l|l|l|}
\hline & 2004 & 2005 & 2006 & 2007 & 2008 & 2009 & 2010 & 2011 & 2012 \\
\hline Bolivia & 127.56 & 121.77 & 128.03 & 132.80 & 129.82 & 128.78 & 154.85 & 140.28 & 136.47 \\
\hline Korea & 528.77 & 527.95 & 536.53 & 551.21 & 563.43 & 577.86 & 626.88 & 654.86 & 661.39 \\
\hline
\end{tabular}

Table 3: GHG data - Total GHG emissions including land-use change and forestry $\left({\mathrm{Mt} \mathrm{CO}_{2} \mathrm{e}-}^{-}\right.$ Million metric tons of carbon dioxide equivalent). Source: CAIT Climate Data Explorer, 2015.

Washington, DC: World Resources Institute. Available online at: http://cait.wri.org.

Greenhouse Gas emissions have decreased since 2010 (see Table 3). Moreover, where Bolivia formerly had one of the highest deforestation rates in the world (UN-REDD 2010), this has dropped dramatically: By 64\% since 2010. The official government data on this, from the Bolivia Forest and Land Authority (ABT) (see Andersen 2014) corresponds to independent data (Hansen 2013). Fuentes (2015) points out that 2010 is the year the government officially opposed carbon offset schemes, set up a state body to protect forest areas, and put large areas of forest under the management of local indigenous people - all programs that fit with the principles of Living Well.

There have also been a number of environmental improvements that impact on daily life. For example, improvements to local transport systems have focused on benefitting low income groups, such as the new cable car public transit system in La Paz (Figure 2). In addition, there have also been new Government initiatives to improve quality and access to water, such as the 'Mi Aqua' program which is extending improved water coverage throughout the country (Slunge and von Walter 2013).

Within the Living Well paradigm, there has also been an emphasis on reviving local traditions and knowledge. For example, traditional medicine, which is much less likely to have a negative environmental impact than the polluting pharmaceuticals used in allopathic medicine (see for example, Kümmerer 2009), is now being promoted by the State. The Government is intent, not only on creating a national system of traditional medicine, but ensuring that it has the same status as Western medicine (Johnson 2010). At the same time, nutritious indigenous crops that have fallen out of widespread popular consumption (e.g. grains such as quinoa and amaranth) are now being promoted (Johnson 2010). 


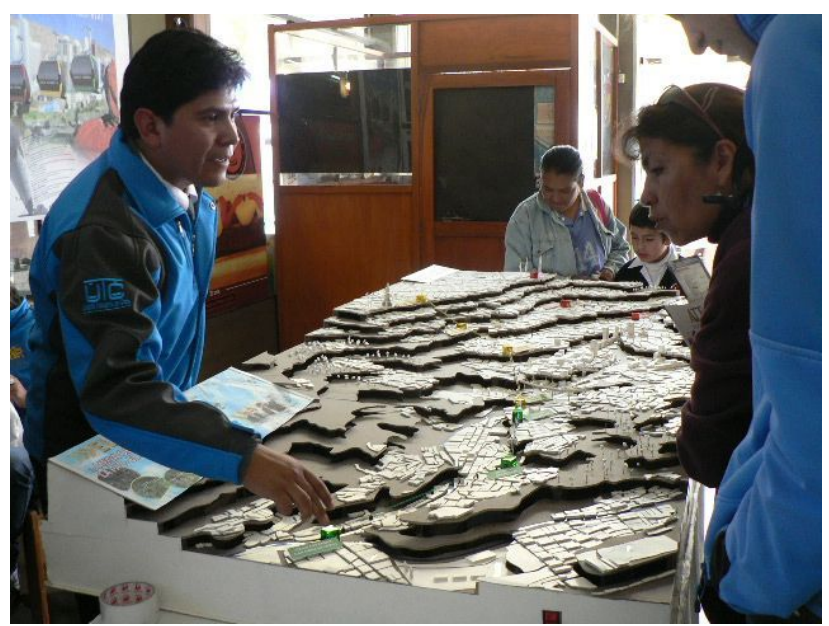

Figure 2: Consultation on new cable car public transit system for La Paz Source: Karen Bell (2013).

Social indicators have also improved, with poverty and inequality rates reducing dramatically in recent years as a result of redistributive measures. According to Bolivia's National Institute of Statistics, poverty levels fell from 60.6 percent in 2005 to 49.6 percent in 2010, with the greatest reduction occurring in rural areas (from 77.6 percent to 65.1 percent) (INE Bolivia 2013). Recent international figures back these findings, indicating that there has been a significant drop in absolute poverty rates (the proportion of those living on less than US\$2 per day) from 60 percent in 2006 to 30 percent in 2011 (CIA 2011). This is, in part, because the minimum wage has increased by 127 percent since 2005, outpacing the rate of inflation. However, the main programs to reduce poverty and inequality have been transfer payments targeting the most vulnerable groups, a national pension and social security scheme (Renta Dignidad), and a national health insurance program for under 25s (interview, 8 April 2013, Magdalena Lázaro, General Secretary of the National Confederation of Indigenous Women of Bolivia - Bartolina Sisa). In addition illiteracy, which stood at over 13 percent of the population in 2006 was eradicated after a 33 month campaign (UNESCO 2009). There has also been a reduction in the proportion of the urban population living in slums (i.e. dwellings which are overcrowded, made of non-durable material, or without access to improved water or sanitation services), which has fallen from 54.3 percent in 2000 to 47.3 percent in 2009 (UNDP 2012). Furthermore, there have been inroads into reducing inequality. According to Government statistical data, the Gini Coefficient dropped from 0.62 in 2005 to 0.53 in 2009, the latest date for which there are figures (INE, Bolivia 2013). Hence, the UNDP Human Development Index rating has also improved for Bolivia (whilst it has stayed the same for Korea) (see Table 4). Though the HDI may be better in Korea, it is the change that has occurred since the initiation of these divergent policies that is indicative of the usefulness of the policy paradigm. Arguably, it is easier to make improvements from a lower starting point but this evidence is still worth considering in the context of the other data discussed here.

\begin{tabular}{|c|c|c|c|c|c|c|c|c|c|c|c|}
\hline & 2004 & 2005 & 2006 & 2007 & 2008 & 2009 & 2010 & 2011 & 2012 & 2013 & 2014 \\
\hline Bolivia & \multicolumn{6}{|c|}{ No data for this period } & 0.6 & 0.6 & 0.6 & 0.7 & 0.7 \\
\hline Korea & \multicolumn{6}{|c|}{ No data for this period } & 0.9 & 0.9 & 0.9 & 0.9 & 0.9 \\
\hline
\end{tabular}

Table 4: UNDP HDI. Source: UNDP HDI http://hdr.undp.org/en/countries/profiles 
As well as the aforementioned national impacts, Living Well is also beginning to have international consequences. In 2010, a global victory for Vivir Bien occurred when the UN voted unanimously to accept Bolivia's proposal to make water and sanitation a human right. Introducing the text, Bolivia's representative said these rights had not been fully recognized, despite references to it in various international instruments, and called on states and international organizations to scale up their efforts to provide safe, accessible and affordable drinking water and sanitation for all (UN General Assembly 2010). Most counties (122) voted in favor of the resolution (though South Korea was one of the 41 countries that abstained).

The Vivir Bien approach is also evident in Bolivia's unique position on the world stage to the issue of climate change. The Bolivian government has taken a principled position in the United Nations climate change negotiations, pushing for a binding, ambitious and justice-based agreement. For example, in December 2009, at the UN Conference of the Parties in Copenhagen (COP15), Bolivia advocated climate reparations from the Global North to the South, and called for a 1 degree Celsius maximum limit on temperature increases.

Living Well in Bolivia has been praised and condemned internationally and internally. For example, Globe International and the Grantham Research Institute on Climate Change and the Environment at the London School of Economics, described the new Framework Law in positive terms as a 'sweeping overhaul' of the national management of natural resources, climate and ecosystems (Nachmany et al. 2014). However, it also criticized the policy for a lack of quantifiable targets that would make it possible to assess its implementation, something the government is now working on.

The policy has also been criticized for being anti-modern, though this is mainly an allegation made by those that are external to the country. For example, a US based blogger vehemently announced "Bolivia is being run by anti-economic socialists, anti-science astrologists, and anti-biology organicists" (Hicks 2012). Yet, there is no dismissal of modernity or science within the Living Well approach. State-sponsored science and technology projects are increasingly prominent in Bolivia and much is being done to foster work in these fields, though with an emphasis on using local materials and methods and respecting indigenous or ancestral knowledge (Centellas 2010). In addition to these criticisms, here have also been accusations that the government is not really committed to the Living Well ideals it professes. This critique was evident in some of the research interviews. For example, it was alleged that the new Framework Law was not sufficiently strong with regard to environmental protection or indigenous rights, as in the following excerpt:

There is a discourse from the Government which gives an international impression but, in Bolivia, they are continuing with these practices that cause environmental and social problems ... The Government maintains the discourse of Vivir Bien but takes the road of industrialisation... (interview, 20 March 2013, Martin Vilela, International Relations representative of the Bolivian Platform on Climate Change).

Criticisms have particularly centered on Bolivia's continuing development of extractive industries and infrastructure projects. In particular, there was a widespread outcry surrounding the building of a road through Isiboro Ségure Indigenous Territory and National Park (TIPNIS) in the central lowlands of Bolivia. The international media and some academics focused on these protests and the supposed hypocrisy of the Government, in particular Evo Morales, in wishing to build a road through a sensitive ecosystem (e.g. Zimmerer 2013: 7).

International environmental NGOs, as well as less formal groups and local organizations, including the lowland indigenous federation, CIDOB, argued that the construction of the road would be ecologically and socially very damaging. Some groups on the left accused the Government of pursuing pro-capitalist development at the expense of the rights of indigenous people, considering the road to be mainly a means of facilitating hydrocarbon exploration and extraction. In some cases, the protesters and NGOs involved proposed that the area be designated as untouchable i.e. as a sacred space, not to be altered.

However, the Government and its supporters, including a large proportion of indigenous communities, considered the road to be essential to bring services to the people living in the TIPNIS region. Far from indigenous people opposing the Government, as the media tended to portray it, the TIPNIS situation was 
characterized by conflicts between the different social movements and between various indigenous groups. These take very different positions with regard to a number of environmental and social issues, in part due to the history of the formation of these groups and movements. Some, often supported by international NGOs, anthropologists and religious groups, have organized specifically around identity, ethnicity and culture, for example, the Confederación Indígena del Oriente Boliviano (Indigenous Federation of Eastern BoliviaCIDOB). Others have focused more on class or a critique of capitalism, for example, the predominately Aymara and Quechua highland campesinos who have formed the Sole Union Confederation of Bolivian Campesino Workers of Bolivia (CSUTCB), the Union Confederation of Bolivian Colonisers (CSCB) and the National Federation of Bolivian Campesino Women-Bartolina Sisa (FNMCB-BS) (Postero, 2010). Therefore, though CIDOB and other groups were opposed to the TIPNIS road, the main campesino groups (largely indigenous), leaders from the Bolivian Workers Central (COB) and indigenous groups in the south of TIPNIS, all came out in support of a road, highlighting the benefits the road would bring in terms of access to basic services and ability to trade.

In October 2011, the Government responded to the protests by passing Law 180, prohibiting the construction of a road through TIPNIS and designating it as untouchable. Even so, protests continued, this time from the supporters of the road, on the grounds that an untouchable status would undermine the livelihood of some of the local people. Consequently, the Government set up a consultation process regarding whether the road should be constructed through TIPNIS and if the area should be designated as untouchable . When the extended consultation process ended in December 2012, the result was that, of the 69 indigenous communities included, 54 agreed to support the road, 3 were opposed to the road only but were also against untouchable status, 1 was opposed to the road and supported untouchable status, and 11 did not participate (6 could not be reached and 5 boycotted the process) (Supreme Electoral Tribunal - TSE, Bolivia, 2013). Many saw this as a triumph for participatory democracy, while others continue to allege that the consultation was manipulated, for example through linking the construction of the road to the promise of clinics and schools.

Though, superficially, the issues seemed to be about whether the provision of services and economic development override the rights of the local indigenous communities, this is in the context of a much larger question about how to meet the needs of some groups, whilst respecting nature and the needs of others. The TIPNIS situation shows that the Government have followed the popular will, and shown a willingness to consult and enter into dialogue. In this example and others, the MAS administration tries to steer a course between environmentalism and developmentalism, which it considers to be the essence of Vivir Bien (see Bell 2014 for more on TIPNIS). Fuentes (2015) argues that the worldwide focus on TIPNIS as proof of the government's anti-environmentalism seems inconsistent with the Government's actual environmental record, particularly in that it presided over a two-thirds reduction in deforestation. He argues that this negative discourse on Morales' environmental record occurs because those making these arguments disagree with his radical approach to the climate crisis and his critique of capitalism.

However, it must be acknowledged that dependency on extractivism is a serious constraint to the effective implementation of Living Well. It is apparent that Bolivia is still tied to this model, even though the share of income from these industries that goes to the state has increased significantly under the MAS administration, enabling the Government to introduce new programs in health, education and social security. Even so, it has not yet been sufficient to enable Bolivia to build a broader basis for income or employment.

Whilst Bolivia continues to increase its extraction of natural resources (Vargas and Gómez 2013), the Government and most of its supporters see this as a temporary necessity with the aim of eventually breaking the country's dependency on extractivism. For example, a recent decision to allow oil and gas drilling in a national park was permitted because it was considered that modern 3D seismology techniques can locate and extract in an extremely precise manner which would disturb less than $0.1 \%$ of the area of the national park. The income from the extraction could be used to preserve the park and develop other sustainability projects, including clean energy and reforestation (Andersen 2015).

It is important to take into account Bolivia's relatively recent and extensive colonial history, which has kept the country poor despite its resource wealth, and which continues to limit its options. In addition, we need to see Living Well in context as a relatively recent policy introduction. It is not yet significantly developed as a concept or as a practical program. Without this work, it is open to a variety of interpretations, 
some of which may not result in a truly eco-social transition. The interviews and discussions I carried out in Bolivia indicate that, though most people in Bolivia are aware of the concept, they were not clear what it would mean in practice. For example, a Government officer responsible for carrying out environmental consultations said:

If you ask me, I do not understand very well what Vivir Bien is. Vivir Bien, the Law of Mother Earth, that paradigm is really new and I have not had the opportunity to understand and ask questions... so it has to be socialised ... I think it is a culture, it is not a simple law. For example, for me, Vivir Bien is very different to what it would be if you asked people from the country. I do not really understand it. We are not really working on Vivir Bien at the moment (interview, 27 March 2013, Senior Environmental Manager, Ministry of Public Works, Services and Housing).

Others had clearer conceptions but with diverse emphases. Some focused on Vivir Bien as part of a transition to socialism and liberation from external domination. For example, a MAS representative said:

For me, Vivir Bien, is our Andean cosmo-vision. We are a pluri-national state so we are at this stage of finding our path to Vivir Bien. The path before was that of capitalism, that of the rich, now it is that of the people, to serve the people. Therefore, now our pluri-national state is taking the path of the people. We are recuperating all that we have lost and forgotten ... (interview, 4 April 2013, Leonida Zurita Vargas, Secretary of International Relations, MAS).

Others emphasized the right to basic services, as in the following comment:

Vivir Bien is to live in harmony, to achieve food sovereignty, value our products, our healthy food, to guarantee the right to water, electricity, basic services to all the population (interview, 8 April 2013, Juanita Ancieta Orellana, Executive secretary of the National Confederation of Indigenous Women of Bolivia -Bartolina Sisa).

These diverse understandings reflect the various dimensions of Vivir Bien - meeting human needs, observing environmental limits, respecting rights, ensuring participatory decision-making and reciprocity. In general, though, there is a clear goal to achieve social progress through redistributive means, rather than through market-based growth. That is not to say that there has not been growth, as it has been quite strong (World Bank 2015b; Table 5), but the Bolivian Government does not focus on growth as the primary route out of the country's problems and Living Well is not expected to be achieved as a spill-over from growth. Growth has occurred as a result of increased external demand for the country's natural resources alongside higher tax burdens on the hydrocarbons and mining sectors (Beatriz and Horatio 2015). The Living Well paradigm does not seek growth per se, unlike in the Green Economy paradigm, where it is a key goal and measure of success.

\begin{tabular}{|l|l|l|l|l|l|l|l|l|l|l|l|}
\hline & 2004 & 2005 & 2006 & 2007 & 2008 & 2009 & 2010 & 2011 & 2012 & 2013 & 2014 \\
\hline Bolivia & 4.2 & 4.4 & 4.8 & 4.6 & 6.1 & 3.4 & 4.1 & 5.2 & 5.1 & 6.8 & 5.5 \\
\hline Korea & 4.9 & 3.9 & 5.2 & 5.5 & 2.8 & 0.7 & 6.5 & 3.7 & 2.3 & 2.9 & 3.3 \\
\hline
\end{tabular}

Table 5: GDP Growth in Bolivia and Kore. Source: World Bank 2015 GDP growth (annual) http://data.worldbank.org/indicator/NY.GDP.MKTP.KD.ZG 
Hence, Bolivia's notion of Living Well incorporates a wide range of aspirations: for decent employment, a living wage, freedom from violence, healthcare and access to essential services like water and sanitation. It does not completely reject industrialization, growth or even extractivism but is based on an awareness of their limits and their need for containment. Though the environmental and social results of the Living Well policy are still uncertain, they look promising, with some important early impacts clearly evident, both national and international.

\section{Achieving an effective and equitable green transition}

The data collated here are indicative of eco-social transition being more equitable and effectively delivered through a Living Well, rather than a Green Economy, approach. However, the national examples also show that there are no simple green transitions and there is much that remains to be debated and researched. It is very early days to see the full impact of these policies, especially in the case of Bolivia which only passed the Framework Law on Living Well in 2012. Impacts have not yet been formally assessed and, in some cases, longer-term time series data are needed to fully establish whether these are genuine trends, rather than just fluctuations. Therefore, it has only been possible to examine the practical application of these paradigms in a very limited way.

It is evident that there is some overlap in approaches, to the extent that both Green Economy and Living Well are based on an appreciation that we are living in a way which cannot be sustained in the future and which is often at the cost of human health and wellbeing. Both paradigms recognize that we need a fundamental change in order to address the multiple crises that we now face. There are a number of programs that would fit in Green Economy and Living Well scenarios, including various forms of dematerialization (reducing the amount of raw materials needed), including remanufacturing, zero-waste, closed-loop systems (where waste products are reused), producing more durable and repairable goods, and using human rather than mechanical labor. However, despite some overlap between these macro-policies, Green Economy and Living Well are competing paradigms, primarily because of their divergent assumptions about the role of the market and the necessity for achieving social equality when addressing environmental problems. The question of which is the most appropriate and effective direction to take is, therefore, fundamental.

The Green Economy, as interpreted in South Korea, is based on an assumption that the market and new technology will bring about the required changes, given the support of governments and their ability to create the right enabling conditions. It is, therefore, very close to the familiar 'sustainable development' and 'ecological modernization' development paradigms. It intends to use the same tools: the market, technological innovation, and peripheral regulation (minor legal reforms) that resulted in the current environmental, economic and social problems. This lack of radicalism would suggest, as other critics have argued, that it will not bring about the fundamental shift that appears to be necessary (Aşici and Bünül 2012; Brand 2012; Kosoy and Corbera 2010). Components of the South Korean Green Economy could work well for addressing specific environmental problems, such as reducing greenhouse gas emissions (mainly via nuclear technology). But the approach could well cause numerous other problems since it fails to take a holistic approach to social, environmental and economic problems. On the other hand, the Living Well scenario promises to achieve an environmentally sound and socially just green transition, but currently these objectives still clash somewhat with Bolivian extractivism.

Both approaches would benefit from taking as holistic an approach as possible when developing their policy paradigms. Rather than compromising between various aspects of the environmental, social and economic, they could be devising strategies that integrate these aspects, though openly discussing shortcomings and attempting to integrate tensions. This would require a strong cross departmental culture and secure spaces which enable policy makers to be creative and focus on wider societal goals. It would also be helpful if researchers and commentators aided this process through creating opportunities for more interactive and open debate around these opposing policy directions.

Cook et al. (2012) have been at the forefront of this debate, asserting that we need a 'green society', and not just a green economy. They advocate that Green Economy could be stronger though incorporating social dimensions into problem definitions at an earlier stage. In addition, they propose that policy responses 
could include transformative social policy that drives structural change. As the United Nations Research Institute for Social Development (UNRISD) point out, unless the underlying inequality of the current economic growth model and power structures is also addressed, it will be difficult to achieve greater equality and reduced poverty through the Green Economy (UNRISD 2012).

Arguably, the most worrying aspect of a Green Economy, as practiced in South Korea, is that it maintains the dominant hegemonic commitment to economic growth at a time when the evidence is mounting that it needs to end. Growth is not necessary to deliver social goals, though it could be useful if accompanied by strong redistributive policies. Evidence shows that, whilst growth can reduce poverty to some extent, it is a blunt instrument, since it is distribution neutral. Several studies have noted that, rather than growth, redistribution of current income and assets is the most effective form of poverty reduction (e.g. Dagdeviren et al. 2001; Gordon et al. 2003; Gordon 2004). For example, in 2004, Gordon argued that a relatively modest amount of redistribution would have easily halved world poverty by 2015, whilst economic growth by itself would have been unlikely to do so. To eradicate child poverty forever, most countries would require an investment of less than 0.5 percent of their GNP, if it could be targeted perfectly (Gordon et al. 2003). Economic growth is probably not necessary, then, to reduce poverty and inequality, and certainly not the most effective method, as both can be more reliably reduced through redistribution. What is likely to achieve this is progressive taxation or, better still, more equal pay; alongside appropriate environmental, economic and social regulation. Whilst Living Well does not explicitly advocate degrowth, it emphasises redistribution, rather than growth as the main mechanism to meet human needs. Hence, taxation of the wealthy, income transfers and sharing of public goods can and will be the main mechanisms for reducing poverty, meeting human needs and achieving ecological sustainability.

It is also evident that a socially just green transition will need to occur hand-in-hand with extensive redistribution of income and wealth on a national and global level. As the trades union movement states, because the global poor need to consume more, the wealthy need to drastically reduce their consumption - by as much as 90 percent over the next few decades (UNEP/ILO/IOE/ITUC 2008). This is very unlikely to happen voluntarily, and so governmental policies which bring about a redistribution of wealth must be the basis for the necessary process of change. The incorporation of Living Well into the Bolivian national development project, if it is able to resolve the constraints and tensions that currently exist, could be an inspiring example of what is possible from national redistribution of wealth. This could also be scaled up to the international level, through the climate reparations that Bolivia is requesting to transfer finances from the Global North to the Global South.

Hence, 'Living well' provides a powerful counter-argument to the capitalist model of sustainability that has become so widely accepted and it promotes survival and satisfaction as ultimately shared achievements. It encourages us to think about what it really means to 'live well', and challenges the mainstream notion of development which emphasizes economic growth, instead focusing on meaningful livelihoods, strengthening social relations, and fostering a harmonious co-existence with nature (Ruttenberg 2013).

These are critical times, and this calls for radical and rational action based on open discussion of the bigger questions regarding how to integrate social, environmental and economic goals. What is particularly evident from an analysis of these countries is that creating socially, environmentally and economically sustainable development is fundamentally a political and policy quest. This requires an open and interactive examination of the challenges, constraints and tensions faced in securing social progress within environmental limits. To this end, academics, policy makers and politicians can work to provide democratic spaces for further debate around these diverse policy options and, more generally, how to implement an eco-social transition which will offer hope to all those who are currently living in material poverty and emotional despair around the world.

\section{References}

Andersen, L.E. 2014. Mission accomplished or too good to be true? La Paz, Bolivia: Institute of Advanced Development Studies.

Andersen, L.E. 2015. Oil exploitation in protected areas - a contradiction in terms? La Paz, Bolivia: Institute of Advanced Development Studies. 
Aşici, A.A. and Z. Bünül. 2012. Green New Deal: a green way out of the crisis? Environmental Policy and Governance 22: 295-306.

Beatriz, M.H. and V.C. Horacio, 2015. Cycles versus trends: the effects of economic growth on earnings in Bolivia. Development Research Working Paper Series 08/2015. La Paz, Bolivia: Institute of Advanced Development Studies.

Brand, U. 2012. Green Economy - the next oxymoron? No lessons learned from failures of implementing sustainable development. GAIA 21(10): 28-32.

Bell, K. 2014. Achieving environmental justice: a cross-national analysis. Bristol: Policy Press.

Bell, K. 2015. Can the capitalist economic system deliver environmental justice? Environmental Research Letters 10: 125017.

Borel-Saladin, J.M. and I.N. Turok. 2013. The Green Economy: incremental change or transformation? Environmental Policy and Governance 23 (4): 209-220.

Brockington, D. 2012. A radically conservative vision? The challenge of UNEP's 'Towards a Green Economy.' Development and Change 43 (1): 409-422.

Burke, B. and Shear, S. 2014. Introduction: engaged scholarship for non-capitalist political ecologies. Journal of Political Ecology 21: 127-144

Centellas, K.M. 2010. The localism of Bolivian science tradition, policy, and projects. Latin American Perspectives 37 (3): 160-175.

CIA (Central Intelligence Agency). 2011. Factbook, 2011. [accessed 12 December 2013]. https://www.cia.gov/library/publications/the-world-factbook/geos/bl.html

Cook, S., Smith, K. and P. Utting. 2012. Green Economy or green society? Contestation and policies for a fair transition. Occasional Paper 10: Social dimensions of Green Economy and sustainable development. Geneva: United Nations Research Institute for Social Development.

COP15 Korea NGOs Network. 2009. Korea's Green Growth = Extraordinary "Green Wash" [accessed 8 February 2014]. http://green-korea.tistory.com/101

Cortés, D. 2014. Presentation on Living Well, The 2nd Climate Legislation Summit. Globe International. February 27-28 2014. Washington, D.C.: U.S. Senate.

Duit A., Feindt, P.H. and J. Meadowcroft. 2016. Greening Leviathan: the rise of the environmental state? Environmental Politics 25:(1): 1-23.

FAO. 2013. Hunger portal. Food and Agriculture Organisation of the United Nations. [accessed 8 February 2014] www.fao.org/hunger/en/

Farthing, L. and B. Kohl. 2010. Social control Bolivia's new approach to coca reduction. Latin American Perspectives 37(4): 197-213.

Ferguson, P. 2015. The Green Economy agenda. Environmental Politics 24(1): 17-37.

GGGI (Global Green Growth Institute). 2011. Green Growth in motion: sharing Korean experience. Seoul, Korea: GGGI.

GGGI. 2013. Overview. Seoul Korea: GGGI [accessed 14 December 2014] http://gggi.org/aboutgggi/organizational/organizational-overview

Gordon, D. 2004. Eradicating poverty in the 21st Century: when will social justice be done? Inaugural lecture, 18th October 2004. School for Policy Studies, University of Bristol.

Gordon, D., Nandy, S., Pantazis, C., Pemberton, S., and P. Townsend. 2003. Child poverty in the developing world. Bristol: Policy Press.

Gough, I. 2013. Climate change, social policy and global governance. Journal of International and Comparative Social Policy 29(3): 185-203.

Gough. I. 2016.Welfare states and environmental states: a comparative analysis. Environmental Politics 25(1): 24-47.

Gudynas, E. 2010. 'Buen Vivir: Un necesario relanzamiento', Politica y Economia, December 2010, http://www.politicayeconomia.com/2010/12/buen-vivir-un-necesario-relanzamiento 
Gudynas, E. 2013. Extracciones, extractivismos, y extrahecciones: un marco conceptual sobre la apropiación de recursos naturales. Uruguay: Observatorio del Desarrollo/CLAES, Centro Latinoamericano de Ecología Social.

Hicks, S. 2012. Crank economics and astrology in Bolivia. stephenhicks.org

Hinterberger F, Hutterer H, Omann I, Pirgmaier E, Giljum S, Stocker A., and A. Teufel. 2009. What kind of growth is sustainable? Vienna: Samsung Economic Research Institute (SERI).

IEA. 2012. Energy policies of IEA countries. The Republic of Korea: 2012 Review. Paris: International Energy Agency.

IEA. 2013. Energy poverty. Paris: International Energy Agency.

IPCC. 2013. Fifth assessment report (AR5) of the United Nations Intergovernmental Panel on Climate Change. Geneva: IPCC

ITUC. 2014a. ITUC Global Rights Index: the world's worst countries for workers [accessed $2^{\text {th }}$ April 2016] http://www.ituc-csi.org/IMG/pdf/survey_ra_2014_eng_v2.pdf

ITUC. 2014b. International trade unions statement on Korea and Human and trade union rights News. [accessed $2^{\text {th }}$ April 2016]

Johnson, B.B. 2010. Decolonization and its paradoxes: the (re)envisioning of health policy in Bolivia. Latin American Perspectives 37(3): 139-159.

Jones, R.S. and B. Yoo. 2012. Achieving the 'low carbon, green growth' vision in Korea. OECD Economics Department Working Papers No. 964. Paris: OECD Publishing.

Joung-Woo, L., Ky-Won, K., Ho-Gyun, K. and C. Young-Tak. 2012. Socially just, sustainable and dynamic growth for a good society: a case study for Korea. Seoul: Friedrich-Ebert-Stiftung.

Kang, S.I., Oh, J.G., and H. Kim. 2012. Korea's low-carbon green growth strategy. OECD Development Centre Working Papers 310. Paris: OECD Publishing.

Kari-Oca II declaration. Indigenous People's Global Conference on Rio+20 and Mother Earth. 17 June 2012, Museu da República in Rio de Janeiro, Brazil.

Koch, M. and M. Fritz. 2014. Building the eco-social state: do welfare regimes matter? Journal of Social Policy 43: 679-703.

Korea Energy Economics Institute. 2013. Energy Info, Korea. Gyeonggi-do, Korea: Korea Energy Economics Institute.

Korean Environment Statistics Information Service. 2014. [accessed 21 January 2013] http://www.kesis.net/flexapp/KesisFlexApp.jsp

Kosoy, N. and E. Corbera. 2010. Payments for ecosystem services as commodity fetishism. Ecological Economics 69: 1228-1236.

Kümmerer, K. 2009. The presence of pharmaceuticals in the environment due to human use - present knowledge and future challenges. Journal of Environmental Management 90(8): 2354-2366.

Kwon, H-J. 2014. Transition to the 'universal welfare state': the changing meaning of the 'welfare state' in Korea. Harvard-Yenching Institute Working Paper Series.

Magdoff, F. and J.B. Foster. 2011. What every environmentalist needs to know about capitalism. New York: Monthly Review Press.

Ministry of Knowledge Economy. 2009. Strategic road map to develop green energy industry. Seoul, Korea: Ministry of Knowledge Economy.

Molero Simarro, R. and M.J. Paz Antolin. 2012. Development strategy of the MAS in Bolivia: characterization and an early assessment. Development and Change 43 (2): 531-556.

MSD. 2006. Plan estratégico: medicina tradicional y salud intercultural 2006-2010 (Strategic Plan: Traditional Medicine and Intercultural Health). La Paz: Ministerio de Salud y Deportes - Ministry of Health and Sport.

Muhr, T. (ed.). 2013. Counter-globalization and socialism in the 21st century: the Bolivarian Alliance for the Peoples of Our America. London: Routledge. 
Nachmany, M., Fankhauser, S., Townshend, T., Collins, M. Landesman, T., Matthews, A., Pavese, C., Rietig, K., Schleifer, P. and J. Setzer, 2014. The GLOBE climate legislation study: a review of climate change legislation in 66 countries. London: GLOBE International and the Grantham Research Institute.

National Science and Technology Council. 2009. Master plan for green energy. Seoul, Korea: National Science and Technology Council.

NRCS. 2012. Abstracts of NRCS green growth research 2011. Seoul: National Research Council for Economics, Humanities and Social Sciences.

OECD. 2011. Towards green growth. Paris: Organisation for Economic Co-operation and Development.

OECD. 2012a. OECD and green growth. Paris: Organisation for Economic Co-operation and Development.

OECD. 2012b. Economic Survey of Korea 2012. Paris: Organisation for Economic Co-operation and Development.

OECD. 2012c. Income distribution data review - Korea. http://www.oecd.org/els/soc/OECDIncomeDistributionDataReview-Korea.pdf

Pachero, D. 2013. Living-well in harmony and balance with mother earth. La Fundación de la Cordillera y la Universidad de la Cordillera [accessed 12 September 2014] http://ucordillera.edu.bo/descarga/livingwell.pdf

Park, B. 2013. Cultural ambivalence and suicide rates in South Korea. In Colucci, E. and D. Lester (eds.) Suicide and culture. Cambridge, MA: Hogrefe. Pp. 237-262.

People's Summit for Social and Environmental Justice. 2012. Final Declaration of the People's Summit in Rio +20 [accessed $12^{\text {th }}$ September 2014] http://rio20.net/en/propuestas/final-declaration-ofthepeoplepercente2percent80percent99s-summit-in-rio-20

Porritt, J. 2007. Capitalism: as if the world matters. London: Earthscan.

Postero, N. 2010. Morales's MAS government building indigenous popular hegemony in Bolivia. Latin American Perspectives 37 (3): 18-34.

Presidential Council for Future and Vision. 2009. Master plan for 17 new growth engines. Seoul, Korea: Presidential Council for Future and Vision.

Radcliffe, S.A. 2012. Development for a postneoliberal era? Sumak Kawsay, Living Well and the limits to decolonisation in Ecuador. Geoforum 43 (2): 240-249.

Rhee, S.K., Jang, D.C., and Y. Chung 2012. A critical review and new policy framework of low-carbon, green-growth strategy of Korea. In Vazquez-Brust, D. and J. Sarkis (eds.) Green-growth: managing the transition to sustainable capitalism. New York: Springer. Pp. 27-42.

Ringen, S., H.J. Kwon, I. Yi, T. Kim, and J. Lee. 2011. The Korean state and social policy: how South Korea lifted itself from poverty and dictatorship to affluence and democracy. Oxford: Oxford University Press.

Rockström, J., Steffen, W., Noone, K., Persson, Å., Chapin, F.S., Lambin, E.F., and J.A. Foley. 2009. A safe operating space for humanity. Nature 461 (7263): 472-475.

Ruttenberg, T. 2013. Wellbeing economics and buen vivir: development alternatives for inclusive human security. Praxis: the Fletcher Journal of Human Security 28: 68-93.

Sanders, C. 2010. Korea: environmental problems and solutions. Asia-Pacific Business and Technology Report. [accessed $12^{\text {th }}$ September 2014] http://www.biztechreport.com

Shear, B. 2014. Making the green economy: politics, desire, and economic possibility. Journal of Political Ecology 21: 193-209.

Slunge, D. and S. von Walter. 2013. Environment and climate change in Bolivia: challenges and opportunities for development. University of Gothenburg and Swedish University for Agricultural Sciences.

Steffen, W., Richardson, K., J. Rockström et al. 2015. Planetary boundaries: guiding human development on a changing planet. Science 347: 6223.

Sommerer, T. and S. Lim. 2016. The environmental state as a model for the world? An analysis of policy repertoires in 37 countries. Environmental Politics 25(1): 92-115.

TSE. 2013. Tribunal Supremo Electoral, Supreme Electoral Tribunal [accessed 10 August 2015] http://www.oep.org.bo 
UNDESA. 2012. A guidebook to the green economy. UN Division for Sustainable Development.

UNDP. 2011; 2012. International human development indicators. United Nations Development Programme.

UNEP/ILO/IOE/ITUC. 2008. Green jobs: towards decent work in a sustainable, low-carbon world. Geneva: UN Environmental Program.

UNEP. 2010. Overview of the Republic of Korea's National Strategy for Green Growth. Geneva: UN Environmental Program.

UNEP. 2011. Towards a Green Economy: pathways to sustainable development and poverty eradication. Geneva: UN Environmental Program.

UNEP. 2013. The emissions gap report. Geneva: UN Environmental Program.

UNEP. 2013b. Building inclusive green economies: success stories from South - South Cooperation. United Nations Environment Programme. Available at: http://www.unep.org/pdf/UNEPSSCSuccess Stories.pdf

UNEP. 2014. Korea's pathway to a green economy. Geneva: UN Environmental Program. http://www.unep.org/greeneconomy/AdvisoryServices/Korea/tabid/56272/Default.aspx

UNEP. 2015. Multiple pathways to sustainable development: initial findings from the Global South. Geneva: UN Environmental Program.

UNESCO. 2009. Results achieved by the Republic of Bolivia in eradicating illiteracy as a potentially valuable experience in UNESCO's efforts during the United Nations literacy decade (2003-2012). 181 EX/61. UNESCO.

UNICEF/WHO. 2012. Progressing on drinking water and sanitation, 2012 update, based on 2010 data. New York: World Health Organization.

UN General Assembly. 2010. General Assembly adopts resolution recognizing access to clean water, sanitation as human right. Sixty-fourth General Assembly Plenary, $108^{\text {th }}$ Meeting (AM) Department of Public Information, News and Media Division, New York.

UN General Assembly. 2014. Declaration of the summit of heads of state and government of the Group of 77 - for a new world order for Living Well. Santa Cruz, Bolivia. 14-15 June 2014.

UN-REDD (2010) National Programme Document - Bolivia. http://www.unredd.net/index.php?option=com_docman\&task=doc_download\&gid=1685\&Itemid=53

UNRISD. 2012. From Green Economy to green society: bringing the social to Rio + 20. Geneva: United Nations Research Institute for Social Development.

Vargas. C.A. and Gómez, J. 2013. 'Bolivia: ¿El "proceso de cambio" nos conduce al Vivir Bien?' In E. Lander, C. Arze, J. Gómez, P. Ospina and V. Álvarez. Promesas en su laberinto: cambios y continuidades en los gobiernos progresistas de América Latina. La Paz: Instituto de Estudios Ecuatorianos (IEE) / Centro de Estudios para el Desarrollo Laboral y Agrario (CEDLA) / Centro Internacional Miranda (CIM).

Värnik, P. 2012. Suicide in the world. International Journal of Environmental Research and Public Health 9: 760-771.

Victor, P.A. and T. Jackson. 2012. A commentary on UNEP's green economy scenarios. Ecological Economics 77: 11-15.

World Bank. 2012. Inclusive green growth: the pathway to sustainable development. Washington DC: World Bank.

World Bank. 2015a. GDP growth (annual) http://data.worldbank.org/indicator/NY.GDP.MKTP.KD.ZG

World Bank. 2015b. Implementing multidimensional measures of well-being in Bolivia: learning from Bhutan, Ecuador, and Mexico. [accessed 2 March 2016]

Yun, S.-J. 2010. Not so green: a critique of the Republic of Korea's growth strategy. Global Asia [accessed 8 January 2014] www.globalasia.org/V5N2_Summer_2010/Sun-Jin_Yun.html

Zimmerer, K.S. 2015. Environmental governance through "Speaking like an Indigenous State" and respatializing resources: ethical livelihood concepts in Bolivia as versatility or verisimilitude? Geoforum 64: 314-324. 